\title{
CONTESTED TERRAIN OF SUSTAINABLE DEVELOPMENT PARADIGM IN SIERRA LEONE
}

\author{
Emerson Abraham, JACKSON \\ University of Birmingham and Bank of Sierra Leone
}

\begin{abstract}
It is surprising sometimes to note that the term Sustainable Development [SD] as used by people in everyday language is not as well understood by people and therefore, needed some level of contestation on their delivery to ensure nations are able to protect the environment, while at the same time ensuring citizens have decent standard of living without resorting to any form of destruction to the earth's surface. In this article, efforts were explored through qualitative study to address concerns around SD agenda in a country like Sierra Leone where lots of concerns around natural disaster has made it possible for those in authority to take proactive actions in setting up strategies to protect the environment. The outcome of the study shows highlights of concerns around infringement of Human Rights freedom and poverty, whole at the same time, people are ready to be consulted as a way of expressing their views about the direction of SD agendas and its immense benefits to communities and the country as a whole.
\end{abstract}

KEYWORDS: Contested Terrain, Sustainable Development, Political Economy, Qualitative Study, Sierra Leone JEL: B40, Q56, P16

\section{INTRODUCTION}

This critical discourse of sustainable development article is concerned with the choice of alternative to society, particularly in situations where the dictate of political economy direction is geared towards the neo-liberal capitalist approach (Jackson, 2016 and Jackson, forthcoming). Development is an evolving terrain, backed by its additional coinage term 'sustainability', which signify that alternatives must be pursued in order that intended (present and future) actions would help preserve the environment for both the present and unborn generations. In the perspective of Furtado (1975), this idea of an embracement of development paradigm is considered a myth - in fact, he added that economic development, is construed from the understanding "that the poor may one day enjoy the same lifestyles as those who are rich today" is simply unrealisable".

Actions towards development of nations is always placed in contention with traditional values and more so, the aesthetic demise of communual historiography. In as much as the intention of developmental efforts are normally based on the underlying intent of enhancing (the) well-being of people, it can also likely be faced with challenges in a trade-off between present sacrifices in a bid that future gains can be realised. Since the bitter experiences of the financial crisis in the years 2007-09, countries around the world have been working hard at placing emphasis on developmental policies geared towards sustaining the earth's resources - some of these have incorporated core measures around macro-prudential policies to protect a further collapse(s) in the financial system and budgetary sustainability (Ntamatungiro, 2004 and Jackson, 2018c), while others, like the UK new deal approach have addressed topical issues around the curtailment of civil crisis (a redress of the Rio de Janeiro treaty in 1992) and welfare protection for the venerables in time of distress (Jessop, 2012).

\section{JUSTIFICATION, AIM AND OBJECTIVES}

The main rationale for this study was borne out of the misconception of the use of the word sustainable development and its associated noun 'sustainability' by people in Sierra Leone, particularly (political) leaders, whose deeds of redressing the collapsed state of the economy is in contrary with the intent and focus of the concept. The encapsulated phrases "Agenda for change' and 'Sustainable Development Goals $(S D G)$ ' have been used aabusivey and actually, did not fulfil their intended purposes as seen across the country evidently manifested through corrupt institutions, degraded environments, also resulting in a consequential impact of the mudslide witnessed on the 15th August 2017 in the Western Area of Freetown are all attestation of the misuse of the term (Jackson, 2018b).

The main aim of the research was to facilitate (qualitative) means of intellectual discourses around the entire usage of the word 'sustainable development' as portrayed in the political economy terrain in Sierra Leone in a bid to ensuring a transparent pathway to dealing with practical issues are addressed in the fore. In order to address this successfully, the following objectives were used as guiding block for pursuing the research to completion:

- Explore people's understanding of 'sustainable development' concept, based on established literature and its focus in protecting present and future generations.

- Investigate attitude on successive sustainable development programs (Toll Road, Forest preservation through REDD+ agenda, etc) and their benefit / demise to community cohesion.

- Explore the way forward through research opinions on how best people would expect their communities to be sustained. 


\section{HISTORICAL APPROACHES TO SUSTAINABLE DEVELOPMENT PARADIGM AND CONTESTED TERRAIN}

This section provide an Outlook of some key historical steps taken across the world in the lead towards maintaining a sustainable global community. The section also focuses attention on key literatures and developments in an effort to address sustainable development concerns in Sierra Leone.

\subsection{Global Overview}

One could easily ascribe the need for survival by the human race as the root cause(s) of the over-utilisation of the earth's resources and for which a coinage of the concept sustainable development has emerged. Despite the usage of words like sustainability and sustainable development concepts may seem to be something new, when in fact it has actually being in existence as early as in the second half of the 20th century, together with its counterpart synonyms in many other international languages such as French (durabilite' and durable), German as Nachhaltigkeit, which literally meaning 'lastingness', and nachhaltig) and Dutch as duurzaamheid and duurzaam (Du Pisani, 2006 and also Van Zon, 2002). Most strikingly on this, Van Zon (2002: 1, 9 and 10) also pointed out that concern around sustainability issues have always been a concern around the over-utilisation of raw materials to meet human demands, which is also an added problem in addressing agenda in environmental sustainability of the earth's surface area - historically, this can be thought of as being in occurrence since the early time of ancient Egypt, Mesopotamian, Greek and Roman civilisation era, with deforestation resulting in serious loss of soil fertility, and which today is all part of the etymological expression of the sustainability phrase.

Worries surrounding over-utilisation of the earth's resources has never been of high concern until presently, where on a regular basis, there are talks about depletion of the Ozone Layer on account of global warming (Scott et al, 2018 and Houghton and Nassikas, 2018). Also, in many of the countries located in the global south such as Sierra Leone, failure of successive governments to adequately address basic provision in preserving areas considered to be part of the protected reserved zone from human interference has been of serious concern (Jackson, 2015a and 2015b). Historiographical legacy of the earth's depletion dates back as early as in pre-historic time and development experts have made some efforts to document it as highlighted in the publication "Timeline of Sustainable Development (Emergence of Anthropocene)", which takes it back to 200,000 years ago, with the appearance of modern Homo sapiens to future projection 2050 as addressed by Hoornweg (2015).

As awareness continues to grow about the need to sustain the environment, so too is the heightened emphasis from people / professionals from all walks of life to step up their efforts in embracing the terminology of sustainability / sustainable development discourse(s). In many of the specialised institutions across the world, for example the Institute for Development Studies (IDS), University of Sussex, academics like Scoones, Leach, Fairhead and many more have produced plethora of academically challenged research outputs to inform leaders and policy makers about concerns and direction in the pathway of preserving the earth's surface for the benefit of both present and future generations (Leach and Fairhead, 2000:
Scoones, 2018; Scoones et al, 2018). The need for such a call on sustainable development agenda by some of the aforementioned professionals cannot be over-emphasised given their wealth of experiences as researchers across different regions in the world, which is not only considered a problem in the global south, but also equally common to developed economies at different levels.

Equally, there is also a current drive on sustainable development discourses which seem to be highly resounded in the education sector, but more so at higher education level as a championed by academic scholars and researchers. This area of higher education embracement of sustainable development discourses is particularly highlighted by Jackson (2015c and 2017) as a concern in the higher education sector in Sierra Leone, which is thought to be needing an overhaul of both its curriculum provision and as well as adequate structures to ensure competitiveness is set high as a priority in the competitive marketisation of educational provision. In this same token, Sawyer (2004) also raised serious points about the need for quality output by African universities in a bid to improving competitiveness and the long term sustainability in the delivery of education provision.

\subsection{Sustainable Development Occurrences in}

\section{Sierra Leone}

In the process of addressing present day development pattern in Sierra Leone, one should not cease to bring to the fore, colonial infiltration in the name of supporting a pathway to development, while our precious natural wealth were being decided upon by the colonial masters as a way of justifying their continued presence in the country (Jackson, 2018b). One could easily throw light on the selfishness of our colonial master, the Great Britain for her selfishness and lack of interest in uniting ethnic divide in the Sierra Leone economy, while efforts were mainly geared towards masterminding an act of divide between the colony and the protectorate (Lane-Poole, 1911). These in a nutshell can be traced as some of the root cause(s) of problems faced in the process of addressing a wellbalanced and sustainable agenda in the country, later was also exploited by selfish indigenous political leaders.

During the reign of the APC government, there was an applauded embracement of synonyms akin to sustainable development discourse like 'Agenda for change' and 'Sustainable Development Goal' in a bid to salvaging the almost demised state of the economy, which was almost left in collapse after a decade of senseless and brutal civil crisis (Ferme, 2018 and Jackson, 2018b). In view of a review of relevant documentations on the above mentioned development phrases, it is believed that there were some good intentions, but how it all went into chaos would be another phase of research in championing knowledge exploration in the area of sustainable development fora.

Failure on the part of responsible government agencies to adequately monitor areas like the forest reserve for example, can be attributed to present challenges the country is faced with in addressing sustainable development discourses adequately and which may also be attributed to the disaster of the August 15th, 2017 mudslide the country witnessed (Di Chiro, 2018). While officials in the former APC ruling party were still pursuing agenda of (self-centred) development agenda projects, viz-a-vis the Toll road, it was almost as if thoughts were 
completely blighted about how people's views could have been embraced in addressing future concerns about cost to livelihoods and many more.

In view of the aforementioned discourses, Harcourt (2014: 1310) threw light on the New Economics Foundation (NEF, a tink tank founded in 1986) challenges on mainstream thinking pertaining to economic development, environment and social issues, with their new approach geared towards social justice, environmental sustainability and collective well-being. The NEF approach, based on the new deal philosophy, has brought to light, new themes on economic thinking such as 'connected economies', 'natural economies', 'valuing what matters' and 'well-being' - in their views, it is perceived that, the concept of growth does not necessarily bring happiness into the minds of people, but an engineered means of the establishment of dysfunctional and unequal societies, while its continued pace, will eventually result in a situation whereby the planet will become unfit for human habitation'(NEF, 2008, also cured in Harcourt, 2014: 1311).

\section{METHODOLOGY AND DATA ANALYSIS}

The methodology for this research was highly based on qualitative method, through means of open observation and backed by interrogation with selected participants, mainly in the greater Freetown area. The choice of participants was mindfully selected, but with focus on consenting adults over the ages of 18yrs old about their notion of sustainable development concept. In order to make the process quite easy to pursue, questions were modelled on core themes as listed below (and also backed by the researcher's observation of participants' involvement and responses to things happening in their surroundings):
- Core understanding of Sustainable development as a concept

- Political influence on sustainability agenda

- Beneficiaries and reaction to events (natural disasters like Mudslide and developments linked to Agenda for Prosperity and Toll Road Charge) as unfolded in the city.

- Way forward on developments (Political Economy honesty and accountability)

In the process of undertaking this sensitive and much more, philosophically oriented research (Jackson, 2018a and Jackson, 2016b), adequate steps were taken to ensure ethical issues around confidentiality were addressed. As already mentioned, such procedure involve necessary steps to seek consent from participants and also ensuring their personal information are kept confidential at all time, that is from the point of gaining access to the final output of the work. Data analysis was heavyweighted through use of qualitative analysis / interpretation using NVIVO, with some quantitative interpretation emerging through graphical means like charts for simplified analysis.

\section{ANALYTICAL DISCOURSES OF THE SITUATION IN SIERRA LEONE}

\subsection{Summary}

A total of 100 qualitative interviewees were deleted and interviewed in the greater Freetown area throughout 2017, with equal gender balance to ensure issues raised were of equal weighting. With reference to the analysis, the outcome have shown varied views from participants about their understanding of sustainable development in Sierra Leone, which is largely a contested notion, even in the case with developed economies where structures are more or less, adequately set and monitored. Table 1 below provide a summary of the outcome and emerging themes.

\begin{tabular}{|c|c|c|}
\hline $\begin{array}{c}\text { Participation [100 } \\
\text { Interviews with equal } \\
\text { balance of gender] }\end{array}$ & $\begin{array}{l}\text { Guiding Objectives for Exploring } \\
\text { Critical Contestation }\end{array}$ & Extended Themes \\
\hline All participants & $\begin{array}{l}\text { Objective 1: Understanding of } \\
\text { Sustainable Development concept }\end{array}$ & $\begin{array}{c}\text { Livelihood issue as main concern. } \\
\text { Political landscape giving rise to issues of } \\
\text { trust }\end{array}$ \\
\hline All participants & $\begin{array}{c}\text { Objective 2: Investigating attitudes } \\
\text { towards SD programs [e.g., Toll Road, } \\
\text { REDD+ for forest preservation] and } \\
\text { beneficiaries on disaster events [e.g., } \\
\text { Mudslide, etc] }\end{array}$ & $\begin{array}{l}\text { Issues around Toll Road construction [more so } \\
\text { about cost to poor citizens]. } \\
\text { REDD+ explained, and with negative } \\
\text { responses regarding beneficiaries. } \\
\text { Mudslide victim support and relocation }\end{array}$ \\
\hline All participants & $\begin{array}{l}\text { Objective } 3 \text { : Way forward on people's } \\
\text { about sustaining the environment }\end{array}$ & $\begin{array}{c}\text { Consultation with ordinary citizens on } \\
\text { development agendas } \\
\text { Support for ordinary citizens in areas relating } \\
\text { Agriculture and small-scale businesses. } \\
\text { Community cohesion in building agenda for } \\
\text { prosperity. }\end{array}$ \\
\hline
\end{tabular}


Based on the the summarised table above, the information below provide a summary of the outcome from NVIVO which is a qualitative software used by researchers, particularly engaged in social sciences research studies.

\subsection{Discussion of Analysis / Outcomes GUIDING OBJECTIVE 1:}

In order to address the concept of contested Sustainable Development [SD] terrain in the situation with Sierra Leone [Figure 1], it was very good idea to start by getting a view / understanding of the concept. From the result of the interview, it shows that $60 \%$ are aware about it and with the remaining $40 \%$ either not sure or do not have an iota of understanding about what sustainable development is about. This is not a surprise given the high level of illiteracy spanning across the country. It also came about from the interview that, even those who purport to show understanding of it are not really clued up about its full extent in nation building.

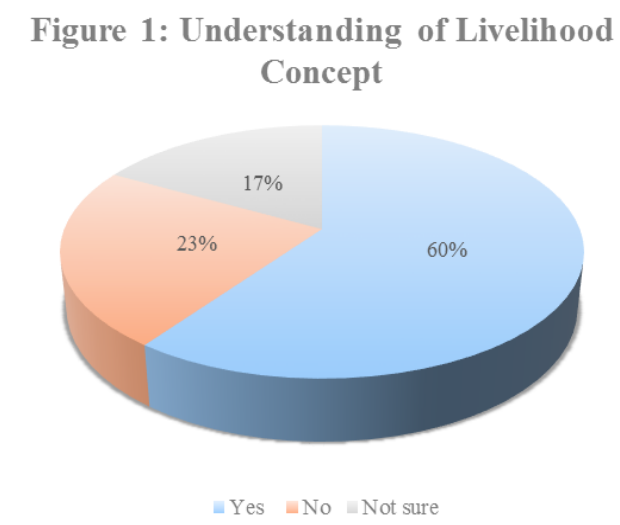

With reference to Figure 2, respondent seem to have expressed general concerns about livelihood issues, which I believe do not work well when it comes to addressing SD agenda in a country like Sierra Leone. About $42 \%$ have expressed concern around poverty, while $30 \%$ shows concern around the quality of education standard and uptake. Other options which include $18 \%$ and $10 \%$ have denoted low level of income and help in the area of support to get starterd eith the ordeal in life respectively. For a country that is working with international partners to promote sustainable development agenda, this sort of responses are considered to be of critical concern.

Figure 2: Livelihood Concern and Issues

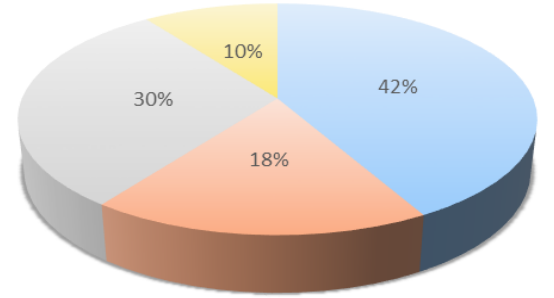

\section{GUIDING OBJECTIVE 2: INVESTIGATING ATTITUDE TOWARDS SD}

This is of critical concern when it comes to contested views from participants connected with SD agenda in Sierra Leone. With reference to Figure 3, 66\% thought Toll Road construction is not a good means of SF project, while $34 \%$ considered it to a good means for SD. Given the state of poverty in the country and particularly in the communities connected with the construction of the Toll Road, it is certain that this will result in serious strain on people's livelihood and restrictive access of movement given the fact that they will be required to pay charges anytime they are ready to move from point A to B along the Toll Road boundary.

With reference to Figure 4, people were asked to list some Figure 3: Toll Road Project as a means of SD

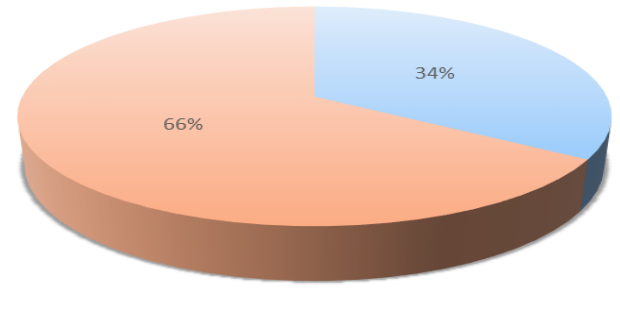

- Yes $=$ No

critically contested issues about the construction of a Toll Road the possibility of poverty rising is $33 \%$, while possibility of Inflationary pressure is recorded at $30 \%$ and restricted access to other locations via the main road is represented by $22 \%$. While Human Rights issues is not so much a high percentage option response $(15 \%)$, it also raises serious issue or concern around the Toll Road construction, particularly so in terms of how people feel about their rights of movement. This is very important consideration when addressing sustainable development agenda. In all fairness, the construction of a proper highway cannot be opposed, but in a situation where the there is limited scope for alternative route(s) for people access other locations around the city, this could be perceived as being of a serious concern to citizens.

Figure 4: Issues around Toll Road construction

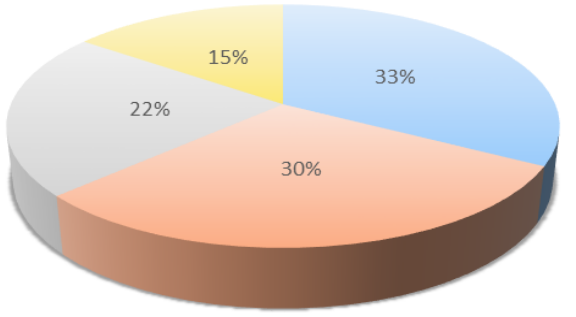

- Increase level of poverty - Possibility of inflationary pressure

Restriction of access to other areas Human rights issues 
Part of the contested area of concern on the SD agenda raised is that of the United Nations 'Reducing Emission from Deforestation and Forest Degradation $[\boldsymbol{R E D D}+]$ '. This idea was rolled into Sierra Leone as part of the UN and other international agencies plan to help Sierra Leone and many developing countries control abuse of its natural environment (Jackson, 2018 b). This in effect then came through some form of financial incentive for people to minimise their abuse / over-utilisation of forest environment, but also supporting them through schemes like agroforestry and financial incentives to seek alternative means of survival. Based on the two responses around this question, it seemed quite obvious that $88 \%$ of respondents have no clue, while only about $12 \%$ knew about it.

Figure 5: Understanding of REDD+

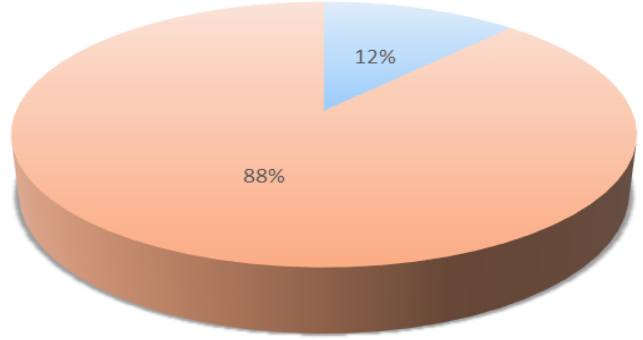

Yes $=$ No

With reference to Figure 6, the event of Mudslide in Freetown last year on the $15^{\text {th }}$ August, 2017 was one of a global concern that made topical story in the media. The relaxed state of control in the country's forest environment by authorities can be blamed for this, but worse around it is the delay and extent of manipulation perpetrated by official concerns in attending to victims. This is considered to be a national disgrace as event like this in all cases should have been treated with urgency as opposed to the extent of its politicisation. In this regard, $92 \%$ manifested great concern around it, while only $8 \%$ felt it was adequately dealt with. Critically, one may be poised to think that there is possibility that some of these minority respondents could have been beneficiaries of packs, while genuine recipients were left in a state of despair.

\section{FigFigure 6: Delay in relocating Mudslide victims}

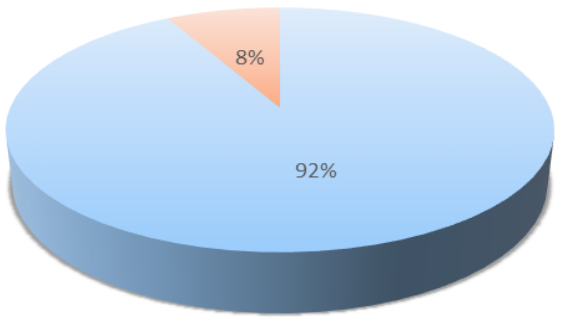

- Yes - No

\section{GUIDING OBJECTIVES 3}

With reference to Figure 7, 100\% percent of respondents felt that it is necessary that consultation is held with citizens to solicit their views about appropriate SD agenda projects that will be of
Figure 7: Consultation with citizens as a way forward for SD agenda in Sierra Leone

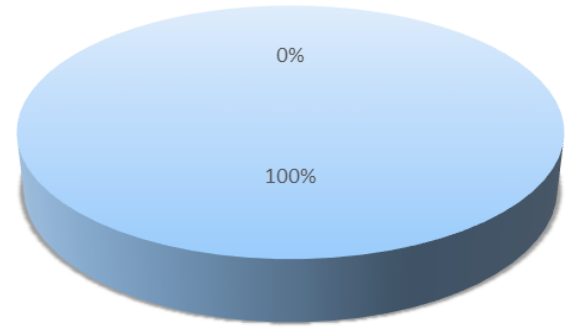

$=$ Yes $=$ No

immense benefit to communities across the country. This is considered appropriate as the voices of people is quite essential in promoting development of a nation.

\section{Figure 8: Preference for future SD agenda in Sierra Leone}

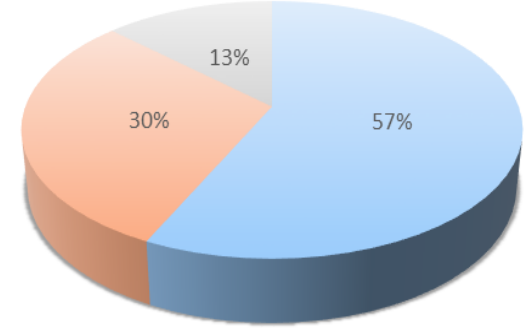

= Investment in Agriculture $\quad$ Reduced level of deforestation $\quad$ Suport through soft loan

Finally, Figure 8 demonstrate people's choices when it comes to what they perceive as the way going forward on SD agenda for Sierra Leone. Investment in Agriculture [57\%] topped the list of priority objectives, while reduction in the current level of deforestation [30\%] and Support through soft loan [13\%] where second and third respectively. This are considered very important priority choices given the state of the country at the moment, which needs complete overhaul of development agendas to ensure sufficient progress is made in the right direction.

\section{CONCLUSION}

In view of the above discussion, it is certain that the state of SD priorities are actually not quite in the direction that it is meant to be, particularly in supporting the long term sustainability of the country's natural resources, while at the same time ensuring people are actively engaged in activities that will seek to support their continued livelihoods without resorting to activities that will impact on the environment. The term contested has been phrased to ensure the topic is dealt with critically through open discourses and responses through qualitative interview were very well supported in that direction as opposed to restricted choices given through closed questionnaire type of method approach.

Critical in this are areas of concern, particularly to residents around the vicinity of the Toll Road who have been given very 
limited option, but to live with the possibility of high cost of living, while for those who are wage or salary earners will be forced to manage with constrained income at the expense of high cost of living. One striking concern in the area of lack of awareness about a lot of the projects that is geared towards supporting SD agenda is the REDD+ scheme, which is a UN funded program; this is co-financed by international organisations like the UN and with high contribution also coming from the Scandinavian bloc of countries to help reduce problems associated with deforestation and ultimately depletion of the earth's environment. It is believed that either that agencies concerned with the publicity of the program were not well engaged with those who needed the support or that it was a mere waste of public resources diverted to irrelevant projects / causes. In a situation where resources are not adequately utilised, then one will consider the situation to be of ethical concern to society and which in future projects of similar nature needs stringent monitoring and evaluation of outcomes reported so as to ensure those deserving the support are in receipt of them at all time.

\section{REFERENCES}

1. Do Chiro, G. (2018). Canaries in the Anthropocene: storytelling as degentrification in urban community sustainability. Journal of Environmental Studies and Science, Online First (2018): pp1-13.

2. Du Pisani, J.A. (2006). Sustainable development - historical roots of the concept. Environmental Sciences, 3:2, 83-96, DOI: $10.1080 / 15693430600688831$.

3. Ferme, M.C. (2018). Out of War: Violence, Trauma, and the Political Imagination in Sierra Leone. USA: University of California Press.

4. Harcourt, W. (2014). The future of capitalism: a consideration of alternatives. Cambridge Journal of Economics, Vol. 38: pp. 1307 - 1328. DOI: $10.1093 /$ cje/bet048.

5. Hoornweg, D. (2015). 'A Cities Approach to Sustainability'. University of Toronto.

6. Houghton, R.A and Nassikas, A.A. (2018). Negative emissions from stopping deforestation and forest degradation, globally. Global change biology, Vol. 24 (1): pp. 350-359.

7. Jackson, E.A. (forthcoming). Triangulation: A Retroduction Approach in the Reorientation of Social Science Research for Central Bank Policy in Sierra Leone.

8. Jackson, E.A. (2018a). Research Methodology in the social sciences: Perspectives on Sierra Leone. USA and UK: Lulu Publishing.

9. Jackson, E.A. (2018b). Political Economy of Forest Ecology in Sierra Leone: A focus on the Western Area Peninsular Forest (WAPFoR). Postmodern Openings, Vol. 9(1): pp. 6390.

10. Jackson, E.A. (2018c). Book Review: Public Debt Management-Theory \& Application. African Journal of Economic and Management Studies, Vol. 9(1): pp. 126-128. DOI: 10.1108/AJEMS-06-2017-0147.

11. Jackson, E.A. (2017). Challenges and Optimism for Sustainable Research Capacity in Sierra Leone. The Journal of Management of Sustainable Development, Vol. 9(1): pp. 43 - 46. DOI: 10.1515/msd-2017-0014.
12. Jackson, E. A. (2016). Ontological and Epistemological Discourse(s) on Sustainable Development: Perspective on Sierra Leone in the Aftermath of a Decade of Civil Unrest. Journal of Management and Sustainable Development, Vol. 8(1): pp. 35-43. DOI: 10.1515/msd-2016-0005.

13. Jackson, E.A. (2016b). Phronesis and the Epistemological Journey through Research Undertakings involving Human Participants in the Context of Sierra Leone. Filosofia Theoretica: Journal of African Philosophy, Culture and Religions, Vol. 5(2): pp. 37-53. . DOI: 10.4314/ft.v5i2.3.

14. Jackson, E.A. (2015a). Negotiating New Dimensions for Forest Conservation in Sierra Leone. Journal of Applied Thought, Vol. 4(2): pp. 86-102.

15. Jackson, E.A. (2015b). FLEGT Mandate: Its applicability and effectiveness in Sierra Leone. Journal of Applied Thought, Vol. 4(3): pp. 84-100.

16. Jackson, E.A. (2015c). Competitiveness in Higher Education Practices in Sierra Leone: A model for Sustainable Growth. Economic Insights - Trends and Challenges, Vol. 4(4): pp. 15-25.

17. Jessop, B. (2012). Economic and ecological crisis: green new deals and no-growth economies. Development Greening the Economy, Vol. 55(1): 17-24.

18. Mallorquin, C. (n/d). Celso Furtado and Development: a brief outline (1950 - 2004). Available at: $<$ http://www.centrocelsofurtado.org.br/arquivos/image/20110 8311518460.MALLORQUIN2.pdf $>$. (Accessed: 23rd July, 2017).

19. Lane-Poole , C. E. (1911). Report on the forest of Sierra Leone. London: Waterlow and Sons Limited.

20. Leach, M., \& Fairhead, J. (2000). Challenging neoMalthusian deforestation analyses in West Africa's dynamic forest landscapes. Population and Development Review, 26(1), 17-43.

21. NEF. (2008). A Green New Deal: joined-up policies to solve the triple crunch of the credit crisis, climate change and high oil prices. Available at: <http://neweconomics.org $>$. (Accessed: 21st July, 2017).

22. Ntamatungiro, J. (2004). Fiscal Sustainability in Heavily Indebted Countries Dependent on Nonrenewable Resources: The Case of Gabon. IMF Working Paper, WP/04/30.

23. Sawyerr, A. (2004). African Universities and the Challenge of Research Capacity Development. JHEA/RESA Vol. 2(1): pp. 211-240.

24. Scoones, I. (2018). Land reform in Zimbabwe: challenges for policy. United Kingdom: Self-publishing (Ian Scoones).

25. Scoones, I., Edelman, M., Borras, S.M (Jr)., Hall, R, Wolforf, W. and White, B. (2018). Emancipatory rural politics: confronting authoritarian populism. The Journal of Peasant Studies, Vol. 45(1): pp. 1-20. DOI: 10.1080/03066150.2017.1339693.

26. Scott, C.E., Monks, S.A., Spracklen, D.V., Arnold, S.R., Forster, P.M., Rap, A., Äijälä, M., Artaxo, P., Carslaw, K.S., Chipperfield, M.P., Ehn, M., Gilardoni, S., Heikkinen, L., Kulmala, M., Petäjä, T., Reddington, C.L.S., L. Rizzo, L.V., Swietlicki, E., Vignati, E., and Wilson, C. (2018). Impact on short-lived climate forcers increases projected warming due to deforestation. Nature Communications, Vol. 9(157): 1-9. DOI: $10.1038 / \mathrm{s} 41467-017-02412-4$. 
27. Van Zon H. 2002. Geschiedenis \& duurzame ontwikkeling. Duurzame ontwikkeling in historisch perspectief: enkele
28. verkenningen. Disciplinaire
Nijmegen/Groningen: Verdieping

Duurzame
Werkgroep Ontwikkeling. 